\title{
T OW DID 22/7 SHAPE THE POLITICAL RHETORIC ON IMMIGRATION \\ 1 AND INTEGRATION IN NORWAY?
}

\section{Nicoleta Carmen Olteanu}

University of Bucharest, E-mail: nico.olteanu@gmail.com

\section{Acknowledgements}

This paper is based on the presentation made at the Fifth international conference on Baltic and Nordic Studies in Romania A piece of culture, a culture of peace, re-imaging European communities in the North Sea, Baltic Sea and Black Sea regions, hosted by Valahia University of Târgovişte and the Romanian Association for Baltic and Nordic Studies, August 17-19, 2014. Supported by EEA Grants, contract no 4/22.07.2014.

\begin{abstract}
:
In Norway, a leading promoter of peace, the attack on the $22^{\text {nd }}$ of July 2011 came as a shock, not merely because of its violence, but also due to the perpetrator's motivation. According to him, multiculturalism undermined Norway and had to be stopped. The act did not only target the direct victims, but also some of Norway's social and political traits. An open democracy and a multicultural society were then being placed under scrutiny. This paper thus focuses on the role of the attack within the subsequent political discourse on immigration and integration in the Norwegian context, discussing how it was shaped by the 22/7 events. Through Critical Discourse Analysis (CDA) this paper identifies the circumstances under which the attack has been referred to (directly or indirectly), the manner in which the events have been portrayed at a political level, as well as the specific approaches of left-wing and right-wing parties and the influence of the attack on their rhetoric. The findings reveal that the event played a role in discourses regarding political, institutional or social issues. It has been portrayed as a violent attack, perpetrated by a lone, mentally ill person; who targeted innocent young people, but also as an act of terror, performed by a right-wing extremist, aimed at challenging the Norwegian state and society. While the major political parties maintained their ideological lines of discourse, the event seems to have moderated their rhetoric.
\end{abstract}

\section{Rezumat:}

In Norvegia, un lider în promovarea păcii, atacul din 22 iulie 2011 a reprezentat un şoc; $n u$ numai din cauza violenței sale, dar și a motivației autorului. In viziunea sa, multiculturalismul compromitea Norvegia și trebuia să fie oprit. Acest eveniment nu a avut ca țintă numai victimele directe, dar și structurile politice și sociale ale Norvegiei. O democraţie deschisă și o societate multiculturală erau puse sub semnul întrebării. Astfel, acest articol se concentrează asupra rolului acestui eveniment $\hat{\imath}$ formarea discursului politic ulterior privind imigrația și integrarea $\hat{\imath}$ context norvegian. Utilizând analiza 
critică de discurs, acest articol identifică circumstanțele in care s-a făcut referire la evenimente (direct sau indirect), modul in care evenimentele au fost reprezentate la nivel politic; precum și abordările partidelor politice de stânga și de dreapta și influența atacurilor asupra retoricii lor. După cum arată rezultatele, evenimentul a jucat un rol în discursul privitor la aspectele politice, instituționale sau sociale. A fost reprezentat ca un atac violent, comis de către o persoană iresponsabilă, care a vizat uciderea unor tineri nevinovați, dar și ca un act terorist, întreprins de către un extremist de dreapta, cu scopul de a arunca mănuşa statului şi societății norvegiene. Deși principalele partide politice iş̦i păstrează elementele ideologice ale retoricii lor, aceasta pare să fi fost moderată prin prisma evenimentelor din Iulie 2011.

Keywords: 22/7, political rhetoric, immigration, integration, multiculturalism

\section{Background}

On the 22nd of July, 2011, Norway's capital city, Oslo, is shaken by an unprecedented event. A bomb explodes in downtown Oslo, affecting the government building and leading to the death of 8 persons. On the same day, several hours later, a second attack occurs on the island of Utøya; where the Labor Party, in power at the time, was holding a summer camp of its youth organization. 69 young people were killed in a shooting-spree.

The immediate reactions in the media saw the events as the doing of Islamic extremists. However, the perpetrator proved to be a native Norwegian, from Western Oslo - Anders Behring Breivik.

Prior to undertaking the attacks, Breivik has published a 1500 page manifesto, a collection of his own and other authors' writings, which among others; addresses the reasons why he resorted to such an act. His purpose was to stop the "decline" of the Norwegian nation and culture; as well as the "islamization" of the country; because of the "multiculturalist elite "1 The manifesto shows his attitudes against immigration and multiculturalism and particularly against those pertaining to the Muslim faith.

After his arrest, Breivik has been trialed and psychiatrically examined. The initial verdict found him insane; however, due to public pressure, a new examination took place, which declared him sane and responsible of his acts. Consequently, he has been sentenced to 21 years in prison; the maximum penalty in the Norwegian justice system.

Breivik had ties with far-right communities, being active in online platforms promoting anti-immigration views; such as the website "document.no" or Peder Are Nøstvold's blog (Fjordman). While claiming to be part of several far right

\footnotetext{
1 Anders BEHRING BREIVIK (Andrew Berwick), 2083 - A European Declaration of Independence,
} p. 31. (pages may differ, since the .pdf file spread in different versions.) 
organizations, he has been a member of the freemasonry ${ }^{2}$, as well as the Progress Party's youth wing. ${ }^{3}$ This liberal-conservative party favors a strict immigration policy and has gained significant electoral support. ${ }^{4}$ Today, it is part of the governing coalition, together with the Conservative Party.

This suggests that there was an environment that could have contributed to Breivik's ideas. In fact, it has been argued that his ideas are common among the right-leaning electorate. Expressing ant-immigration views and concern about cultural issues is considered rather mainstream. ${ }^{5}$ Debates on topics related to immigration, integration, culture or religion are commonly found in the public sphere, either in the media or within political or academic discourse.

There was a certain degree of immigration-skepticism within the Norwegian society; however, the $22^{\text {nd }}$ of July represented a turning point, bringing instant attention to issues related to right-wing extremism, racism and xenophobia. Such an unprecedented event inevitably has an impact on society; as a whole, triggering reactions from different groups. To discover some of these consequences, this paper will focus on the political elite, aiming to analyze the discursive approach of the main political parties, with regards to immigration and integration in Norway, after the 22/7 events. As such, the purpose of this paper is to find whether and how political views have changed, by researching the debate that took place in the period between the attacks and the parliamentary elections in September 2013. The study will thus identify the circumstances under which the attacks have been referred to within political discourse, as well as the way in which the events have been portrayed. Moreover, by analyzing different rhetoric instances of political leaders, this paper will show the influence of the attacks on the discursive approach of major political parties. The main question that will be answered is: How did the events on 22/7/2011 shape the political discourse on immigration and integration in Norway?

This paper will therefore argue that the events that took place in July 2011 have contributed to a more moderate political rhetoric on immigration and integration.

To achieve this, the study focuses on the political debate over immigration and integration in Norway, and analyses statements given by parliamentary party

\footnotetext{
2 "Han var høflig, stille og «pinglete»" (- He was polite, quiet and "puny"), NRK, 28.01.2012, http:/ / www.nrk.no/norge/ losjebrodrene-forteller-om-breivik-1.7971381

2 *** Immigrants and Norwegian-born to immigrant parents, by country background. 1 January, 2014; Statistisk Sentralbyrå, http://www.ssb.no/en/innvbef

3 Eivind FONDENES; Kathleen Buer (23 July 2011). "Terrorsiktede var tidligere medlem av Fremskrittspartiet", TV2, http://www.tv2.no/nyheter/innenriks/terrorsiktede-var-tidligeremedlem-av-fremskrittspartiet-3544743.html

$4 * * *$ The European Election Database, Norway - Political parties, http://www.nsd.uib.no/european_election_database/country/norway/parties.html

${ }^{5}$ Mette WIGGEN (2012) "Rethinking Anti-Immigration Rhetoric after the Oslo and Utøya Terror Attacks", New Political Science, 34:4, 585-604,
} 
politicians and published in two major Norwegian newspapers: Verdens Gang (VG) and Aftenposten, between 22/7/2011 and 9/9/2013. Only direct quotations have been considered. ${ }^{6}$ The articles used throughout the research have been retrieved using the Norwegian equivalent of the following search terms: foreign* (utlend*), immigra* (innvand*), multicult* ${ }^{*}$ multikult*). The terms were partially inserted, to allow the search to retrieve derived words. The search has been performed using the tools provided on the newspapers' websites. After manually filtering irrelevant content, the final batch of source material comprises 333 articles.

This study will employ critical discourse analysis, a type of content analysis that applies critical social analysis to a discourse, using Norman Fairclough's framework ${ }^{7}$. Hence, the object of analysis within this paper will be represented by text, which will be described, interpreted and explained, according to the social, political, cultural and historical context within which it was produced.

Written media has been chosen as the main source of empirical material since it plays a crucial role as a link between different social groups; between decision makers, politicians or state institutions and the general public. In fact, one study showed that after the $22^{\text {nd }}$ of July, the media took the Government's perspective on the events, portraying them as the act of a "lone, evil and deeply disturbed individual." 8

\section{Immigration to Norway: Facts, Figures and Policies}

Norway is a fairly new destination country for immigration. The process began in the 1970's, when oil reserves have been discovered in the North Sea. The newly emerged oil industry needed workforce in order to flourish; and since the country could not cover the necessary human resources by itself, guest workers were brought in. After the 1980-1990s, the conflicts taking place in different areas of the world (several African countries, the Balkans, Iraq, Afghanistan, etc.), have lead to an increasing number of refugees and asylum seekers being received into Norway. Next, after 2004, newcomers arrived from freshly accepted EU members, such as Poland or the Baltic States. In a nutshell, since the 1970's, immigration has increased nearly tenfold. ${ }^{9}$

\footnotetext{
${ }^{6}$ Citations inserted within this paper are translated from Norwegian.

77 See: Norman FAIRCLOUGH (1995) Critical Discourse Analysis. (London, Longman), p. 6.

8 Jesper FALKHEIMER and Eva-Karin Olsson "Depoliticizing terror: The news framing of the terrorist attacks in Norway, 22 July 2011", Media, War $\mathcal{E}$ Conflict, 1 May 2014, p. 12.

9 Norbert BECKMANN-DIERKES, Johann C. Fuhrmann, “Immigration Country Norway Demographic Trends and Political Concepts"; KAS International Reports, 2 |2011, pp. 36-48.
} 
As of January $1^{\text {st }} 2014,14.9 \%$ of Norway's population has an immigrant background. ${ }^{10}$ The most numerous group of immigrants is represented by polish citizens, while most Norwegian-born from immigrant parents are of Pakistani origin (descendants of persons who came from Pakistan to work in the oil industry in the $70 \mathrm{~s})$. The largest population with an immigrant background is found in the Oslo area; where some suburbs are $50 \%$ inhabited by this category of residents. ${ }^{11}$ Additionally, according to the UNHCR, there are 54,425 refugees, asylum seekers and stateless people, currently residing in Norway, ${ }^{12}$

In time, specific immigration policies were developed. Norway implements inclusive measures when it comes to aspects such as the labor market, access to education or participation. A more restrictive approach is taken concerning family reunion (minimum revenue and time of residency conditions need to be met in order to be eligible); as well as access to citizenship; Norway being one of the few countries that do not allow double citizenship. ${ }^{13}$

\section{Party-specific attitudes towards immigration}

The Norwegian political parties evidently have their own specific views on immigration; however there are some aspects, which are generally agreed upon, regardless of political orientation. The parties commonly want more regulated and controlled immigration and asylum processes; they encourage the knowledge of Norwegian language and social norms as one of the main drivers of integration. In addition, the majority favors the expedited return of those who do not reside legally in the country and of those who commit crimes. The views that are specific to certain parties only, shall be discussed hereinafter.

The Labor Party (Arbeidspartiet) is a left wing, social-democratic party that supports controlled immigration. It considers that the country is enriched by diversity, but also points out that "Norway cannot receive everyone who wants to come".14 They encourage tolerance, inclusion and equality of rights and obligations, while expecting that Norway's laws and democratic values be respected in exchange. The protection of refugees and asylum seekers is also being supported; however, the party advocates for a fast return to the home country, when it comes to those who cannot stay, for any particular reason.

\footnotetext{
$10 * * *$ “Immigrants and Norwegian-born to immigrant parents, by country background. 1 January, 2014"; Statistisk Sentralbyrå, http://www.ssb.no/en/innvbef

11 Ibid.

$12 * * *$ “2014 UNHCR regional operations profile - Northern, Western, Central and Southern Europe”, UNHCR, http:/ / www.unhcr.org/pages/49e48ed26.html

13 Exceptions are mainly related to difficulties in citizenship release from the applicant's former country as well as to Norwegian citizens born in Norway and residing abroad.

14 "Innvandring og integrering," (Immigration and Integration) Arbeidspartiet (The Labor Party), http:/ / arbeiderpartiet.no/Politikken-A-AA/Innvandring-og-integrering.
} 
The Socialist Left Party (Sosialistisk Venstrepartiet), generally has a favorable view towards immigration and to a certain extent, advocates for a more permissive approach; in particular when it comes to asylum cases involving children. SV also support better regulation and control of immigration.

The Progress Party (Fremskrittspartiet) identifies itself as classic / conservative liberal. It advocates for strict and limitative immigration policies, especially concerning non-EEA citizens. According to their position, refugees and asylum seekers should only be allowed in Norway if there is a real need for protection. The party also focuses on culture and values, supporting the idea that "It cannot be accepted that fundamental western values and human rights are set aside by the cultures and attitudes that some groups of immigrants bring with them to Norway." $)^{15}$ The party is known for its anti-immigration rhetoric.

The Centre Party (Senterpartiet) is centrist and agrarian and promotes a pragmatic approach in terms of immigration and asylum. They advocate for the establishment of clear rights and obligations, the improvement of asylum processing procedures and also the assurance of the necessary infrastructure in order to support the population. ${ }^{16}$

The Liberal Party (Venstre) is social-liberal and sees immigration as a factor that enriches the Norwegian culture and economy. The party's attitude is generally positive; for instance, it supports double citizenship, increased labor migration and refugee quotas; but also the prompt expulsion of refugees and asylum seekers who commit crimes. ${ }^{17}$

The Conservative Party (Høyre) has a more pragmatic, conservative view, agreeing with increased refugee quotas if necessary, supporting fast expulsion procedures, tighter requirements in terms of asylum seekers' identification and a closer supervision of those who are rejected residency..$^{18}$

The Christian-Democratic Party (Kristelig Folkepartiet) supports the formulation of clearer immigration rules, the acceptance of refugees and asylum seekers who truly need protection, as well as a more effective return process. The

$15 * * * \prime$ Det kan ikke aksepteres at grunnleggende vestlige verdier og menneskerettigheter blir satt til side av kulturer og holdninger som enkelte grupper av innvandrerne tar med seg til Norge", Fremskrittspartiet, (The Progress Party)http://www.frp.no/nor/ mener/En-enklere-hverdag/FrPfra-A-til-AA\#id38159

$16 \quad$ (The Center Party), http://www.senterpartiet.no/i/category12992.html\#_Toc247513954

17 Politikk fra A til $\AA$ (Politics from A to Z), Venstre (The Liberal Party), http:/ / www.venstre.no/artikkel/45742

18***“Innvandring" (Immigration), http://www.hoyre.no/www/politikk/

Høyre (The Conservative Party), /innvandring/ hva_mener_hoyre_om/kommune_og_forvaltning 
party encourages participation and active involvement in the labor market and the reduction of welfare dependency. ${ }^{19}$

The parties that most participated to the analyzed debate are the Labor and Progress Party, as well as The Socialist Left and Conservative Party. Other groups have also contributed; however they have not been opinion leaders; they rather participated to a discussion that was already initiated.

\section{General Discussions}

In the aftermath of the events, everyone, including the political class, tried to make sense of what had happened. A sign of common grief and understanding, as well as of respect for those affected was the period of "civil peace", agreed by all political parties. This meant that all political groups would refrain from any immigration-related discussion, between the 22nd of July and the $13^{\text {th }}$ of August. Additionally, the electoral campaign for the upcoming local elections has also been postponed.

Within the overall debate, parties do their best to distance themselves from Anders Breivik's views. The Progress Party in particular, is dealing with a direct association to Breivik, due to his past membership its youth organization. The Labor Party has been the perpetrator's target, due to the fact that it was allegedly encouraging immigration. Therefore, both parties had reasons to show that they or their political views had no contribution; especially within the context of the local elections taking place very shortly after the incidents.

The attacks have been widely debated during the 22/7 Gjørv commission report, which concluded that the Police forces could have responded better and could have prevented both the attack on the Government building and could have undertaken a faster operation on Utøya. ${ }^{20}$ Next was the perpetrator's trial, in 2012, when besides the overall discussion, political leaders were called to the witness stand 21 , an occasion that again triggered public associations of political actors to Anders Breivik. During the electoral campaign for the parliamentary elections in 2013; however, the discussion took a more pragmatic turn towards

$19 * * *$ "Innvandring og integrering" (Immigration and Integration), Kristelig Folkepartiet, (The Christian Democratic Party) http://www.krf.no/ikbViewer/page/krf/artikkel/hva-menerkrf?p_document_id=3587

20 Thomas BOE HORNBURG, “22. juli-rapporten kommer Frp til unnsetning” (22nd of July Report comes to Progress Party's help), Aftenposten, 14.aug. 2012 http:/ / www.aftenposten.no/meninger/kommentarer/22-juli-rapporten-kommer-Frp-tilunnsetning-6965629.html\#.UyQsf5JP67o

${ }^{21}$ For instance, the Labor Party's Secretary, Raymond Johansen ("We lost our greatest talents"); See Morten Hopperstad, "Partisekretær Raymond Johansen (Ap): Mistet våre fremste talenter", Aftenposten, 06.06.2012, http://www.vg.no/nyheter /innenriks/terrorangrepet-22-julirettssaken/partisekretaer-raymond-johansen-ap-mistet-vaare-fremste-talenter/a/10073600/ 
matters related to asylum, returns and criminality; with fewer direct references to the attacks.

\section{2/7 Portrayals in Political Discourse}

Once analyzing the statements included within the selected newspaper articles, there are a few intertwined images of the attack that may be observed. It is seen as a senseless act, perpetrated on innocent young people; as an event that would mark the Norwegian society; one that would require national introspection In terms of tolerance towards diversity. Furthermore, it is also seen as an act of terror, committed by a right-wing extremist, with connections with far right networks; a terrorist act that targeted the whole of Norway.

These frames are shared throughout the political left and right. For instance, Socialist Left politician Kristin Halvorsen (Minister of Education at the time) notes that: "What has happened is completely incomprehensible". 22 In the immediate aftermath, Progress Party Leader, Siv Jensen, mentions that it was "time for sorrow", stressing that: "Norway is hit by a national tragedy". Similarly, the then Prime Minister Jens Stoltenberg strengthens the idea that the events are of utmost importance to Norway, by stating that this was "an attack on innocent civilians. On young people at a summer camp. On us." and that "It became part of our identity and our history. It will always be with us." This statement also suggests that the events represented a reason for being together, which is also expressed by Siv Jensen, who states that this is the time when "we stand together in grief".

\section{The Influence of 22/7}

\section{on Political Rhetoric Concerning Immigration and Integration}

The analysis of an extensive amount of media material, containing direct quotations of political leader statements related to immigration and integration, has provided conclusive elements showing the specific effects of $22 / 7$ on political rhetoric.

The first and most obvious element to note is that both sides of the political spectrum expressed a high degree of empathy with the victims and to a certain extent, with the Labor Party. For instance, the Progress Party and the Socialist Left Party show such empathy through their statements. Progress Party Leaders Siv Jensen, says: "Today is the day when all 25000 FrP members are AUF-ers." 23 She also shows admiration for the way the Prime Minister, Jens Stoltenberg, stood up and led everyone through a time of crisis. She acknowledges that he has

22- Dyveke NILSSEN „Dette bringer alle i Norge sammen”, (This brings everyone in Norway Together), VG, 26/09/2011, http://www.vg.no/nyheter/innenriks/terrorangrepet-22-juli-politikkog-samfunn/dette-bringer-alle-i-norge-sammen/a/10080718/

23 idem. 
accomplished a difficult task and stresses the respect that he deserves for having achieved this.

"Stoltenberg has stood up and led the country through an unimaginable crisis. It is a heavy leadership responsibility, for any prime minister who would have had to take it. In addition to leading through the crisis, he has succeeded to unite. He has spoken in a way that does not separate, but in a way that unites. He has refrained from political rhetoric. This deserves respect." 24

The Socialist Left Party on the other hand, highlights its support for the victims and all those who need comfort, through Kristin Halvorsen's statements:

"Take care of those who need it! It is important to show them our support. We must reach out to those in need and give them comfort! And not just in the next few days; these people will be marked for a long time!" 25

Both of these statements show a common will for togetherness, for mutual support and understanding, through a time of crisis, that no one could have seen happen. This feeling of togetherness, of a common suffering, led to a certain degree of consensus in the immediate period after the attacks. The fact that politicians agreed to refrain from any comments and debates; as well as the decision to postpone the local elections campaign, show that the attacks made the political class find common ground and gave them enough reasons to acknowledge what their political rivals are doing well (as was the case with Siv Jensen's support for Stoltenberg).

Moreover, it is noticeable that, in the immediate aftermath, the Labor and Progress Party mutually support each other when public opinion and politicians make associations of Breivik's acts to one party or the other. The Foreign Minister Jonas Gahr Støre, of Labor, states: “There is a time for everything, and this is not the time to point fingers at other political parties and their leaders." 26 Similarly, Siv Jensen mentions that: "it is unacceptable that Labor's immigration policy is being blamed for the terror." 27

\footnotetext{
24 *** "Jensen avviser felles tankegods med Breivik" (Jensen rejects Breivik's ideas as common), Aftenposten, 2011 17:14 http://www.aftenposten.no/nyheter/iriks/Jensen-avviser-felles-tankegodsmed-Breivik-5014942.html\#.UySTuZJP67o

25 idem 22.

26 *** "Jonas Gahr Støre går ut mot Frp-anklager" (Jonas Gahr Støre reacts against accusations on the Progress Party), VG, 28/07/2011, http://www.vg.no/nyheter/innenriks/terrorangrepet-22-julipolitikk-og-samfunn/jonas-gahr-stoere-gaar-ut-mot-frp-anklager/a/10080937/

27 Arild FÆERAAS, “Lokal Frp-topp om massedrapene: - De første ofrene for norsk innvandringspolitikk " (Local Progress Party Leader on the Mass Killings - The first victims of Norwegian Immigration Policy), VG, 13/08/2011, http://www.vg.no/nyheter/innenriks/frp/lokal-frp-topp-om-massedrapene-de-foerste-ofrene-fornorsk-innvandringspolitikk/a/10081215/
} 
Furthermore, the subsequent debate shows that the political rhetoric concerning immigration and integration has been moderated. Politicians refrain from using harsh words and party leaders often counteract other party members' statements when they are considered inappropriate.

There was an almost immediate acknowledgement of the fact that political rhetoric on immigration must be moderated. Siv Jensen notes that this would be a huge challenge. She states:

"We who live by using words, think more than ever about the words we use as we don't dare to use those that were natural and proper any more, because they appear to be offensive." 28

Progress Party Mayor in Askøy, Bergen Knut Hanselmann also mentions that: "The terrorist attacks means that the party must stop talking about immigrants ruining the Norwegian culture. “29

Labor party politician, former prime minister and Secretary General of the Council of Europe, Thorbjørn Jagland stresses that: "We must be careful about the words we use, because they can be misused."

Conservative Party Leader Erna Solberg also mentions:

"I hope that in the elections campaign we get a debate that allows us to discuss immigration and integration in a way that makes no one who grew up in the country feel like second-class citizens. The wording is important and can make a difference between a stigmatizing or integrative debate." 30

Jens Stoltenberg also emphasized the importance of a more careful rhetoric, and brought up the need to avoid referring to past statements; calling this a "witch hunt for rhetoric":

"After the 22nd of July there may obviously be something we wish we had formulated differently, in the future we will express with greater sensitivity. [...] I will pray that we do not start a witch-hunt for rhetoric. We all need to say I was wrong - and be respected for it." 31

This statement triggers a new debate that discusses freedom of speech along with the responsibility for 22/7: While some politicians make their opponents responsible, party leadership moderates the discussion.

Labor Party Secretary, Raymond Johanson mentions that: "Freedom of expression is absolute, but freedom also comes with responsibility" while youth

\footnotetext{
28 idem 22.

29 Idem 26.

30 Stine BARSTAD, “Stoltenberg advarer mot heksejakt på ytringer" (Stoltenberg warns against the witch-hunt on rhetoric), VG, 18.okt. 2011, http://www.aftenposten.no/nyheter/iriks/Stoltenbergadvarer-mot-heksejakt-pa-ytringer-6282315.html\#.UyMhiZJP67o

31idem.
} 
organization leader Eskil Pedersen, who survived the attacks, also believes that with freedom of expression comes a freedom of responsibility. This remark was perceived as referring to the Progress Party's accountability for their antiimmigration rhetoric. However, Stoltenberg balances the discussion on freedom of responsibility, by stating:

"I think it is an imprecise term. For I believe that we have a responsibility to express ourselves and to raise objections. Not to deny people to say anything because we think that what they say is stupid." 32

The Progress Party shows the same tendency of expressing apologies or regret, or simply debating against party members' statements. When in November 2011, Progress Politician Per Sandberg stated that the Labor Party was playing the victim after the $22^{\text {nd }}$ of July ${ }^{33}$, Siv Jensen counteracted his statement by saying:

MP Per Sandberg expressed himself unluckily. [...] On behalf of the Progress Party's parliamentary group, I regret this statement" 34

When Progress politician Carl I. Hagen expressed that the post 22nd of July investigation on Utøya is too extensive, Jensen again brings the party leadership perspective into discussion:

"I think that Carl I. Hagen's statements about what the survivors need to know about what happened at Utøya, were formulations that slipped. I think it came as an expression of his own frustration and not as something that the party had thought about carefully." 35

Jensen herself avoids generalizing when talking about sensitive matters. One example is her distinction between Muslims and Islamic extremists: "There is a

\footnotetext{
32 Mads A. ANDERSEN, “Stoltenberg: -'Ytringsansvar» er et upresist begrep" (Freedom of Responsibility is an imprecise term), VB, 22/12/2011, http://www.vg.no/nyheter/innenriks/stoltenberg-regjeringen/stoltenberg-ytringsansvar-er-etupresist-begrep/a/10024756/

33 Eivind SØRLIE, "Sandberg: «Ap har spilt offer» etter 22. Juli" (Sandberg: "Labor has played victim" after 22 July), Aftenposten, Nov 23rd. 2011, http://www.aftenposten. no/nyheter/iriks/Sandberg-Ap-har-spilt-offer-eter-22-juli-6704751.html\#.UyV_TZJP4j8

${ }^{34}$ Helle SKJERVOLD, "Beklaget Sandberg-utspill og angrep Eskil Pedersen" (Sandberg regrets having attacked Eskil Pedersen), Aftenposten, 24.nov. 2011. http://www.aftenposten.no/nyheter/iriks/Beklaget-Sandberg-utspill-og-angrep-Eskil-Pedersen6705791.html\#.UyV_K5JP4j8

35 Hans Henrik TORGERSEN, "Frp-velgerne støtter Hagen etter terror-utspill” (Progress Party Voters Support Hagen with terror-act related initiative), VG, 17.08.2011, http://www.vg.no/nyheter/innenriks/valget-2011/frp-velgerne-stoetter-hagen-etter-terrorutspill/a/10081530/
} 
difference between Muslims and radicalized Islamists who take use religion to achieve political goals." 36

While the Progress Party leader tones down other members' rhetoric, the Labor Party engages in restrictive immigration related policies. For instance, the party undertakes a process of returning asylum seekers who cannot legally stay in the country. Since these cases involved children, this sparked discontent and criticism, including from the coalition partner, the Socialist Left Party. However, the initiative drew support from the Conservative and Progress Party, who did not want any kind of amnesty in these cases; namely those who had children born in Norway should not be exempted from being returned.

Other examples of restrictive approaches from the Labor Party are the Roma beggars' debate, which led to a banning initiative in the Parliament. ${ }^{37}$ A third example is the Gate Magazine case; in which street selling this publication (by immigrants) was not being considered real labor by the party. This activity was only being considered as a way to receive benefits from the Norwegian welfare system.

Furthermore, as the 2013 elections approached, the discussions turned to more pragmatic matters, related to security. For example, Fabian Stang, Oslo's Conservative Party mayor, suggested restrictions on freedom of movement for reception center residents. Mental health investigations performed on asylum seekers were brought up by Oslo's deputy mayor Libe Rieber-Mohn, of Labor. Justice Minister Grete Faremo also discussed fingerprinting residency applicants, mentioning that this will "increase the documentation security. for the residency permit and thus help prevent illegal immigration and illegal stay." 38

\section{Conclusion}

The consensus, mutual understanding and empathy brought the political class together, in a time of crisis. In addition, the unprecedented events have made politicians acknowledge that, regardless of their political orientation, they all need to take greater care for the words they use when communicating to their public. The Progress Party has acknowledged that their discursive approach needed to change. Furthermore, the party leadership has toned down harsher party member

\footnotetext{
36 *** "Siv Jensen: - "Bhatti kan gjerne finne seg et annet land" (Bhatti may well find himself another country), VG, 21.01.2012, http://www.vg.no/nyheter/innenriks/norsk-politikk/siv-jensen-bhattikan-gjerne-finne-seg-et-annet-land/a/10076250/

37 A national begging ban has been rejected, however, local authorities have been granted the choice to decide whether they want to ban begging, in certain areas or completely.

38 Per ANDERS JOHANSEN, "Så lett er det å få falsk identitet i Norge" (A false identity is easy to get in Norway), Aftenposten, 2013 09:25, http://www.aftenposten.no/nyheter/iriks/Sa-lett-er-det-afa-falsk-identitet-i-Norge-7118388.html\#.UyYO_JJP4j
} 
statements, suggesting that Progress wishes to take on a different approach and avoid being associated to Anders Breivik's line of thinking,

The Labor Party, on the other hand, has received empathy and support in the aftermath of the attacks. They have also shown a certain degree of moderation, especially when it comes to holding The Progress Party's rhetoric accountable for the events. Labor's rhetoric has remained balanced and their policy approach has continued along the lines of "strict, but fair".

The Conservative and Socialist Left Party have not shown significant signs that could point to a specific influence from the 2011 events. Neither have the other parliamentary parties, which, as a matter of fact, did not participate so actively in the debates.

The opinion makers remain either the Labor or the Progress Party. They were the most affected in terms of discursive approaches; however not in terms of core political ideologies. Their main guidelines remain the same. What did indeed change was the way things are expressed.

\section{References:}

*** "Han var høflig, stille og «pinglete»" (- He was polite, quiet and "puny"), NRK, 28.01.2012, http://www.nrk.no/norge/ losjebrodrene-forteller-om-breivik-1.7971381

*** "Innvandring og integrering" (Immigration and Integration), Kristelig Folkepartiet, (The Christian Democratic Party) http:/ / www.krf.no/ikbViewer/page/krf/artikkel/hvamenerkrf?p_document_id=3587

*** "Innvandring" (Immigration), Høyre (The Conservative Party), http://www.hoyre.no/www/ politikk/hva_mener_hoyre_om/kommune_og_forvaltning /innvandring/

*** "Jensen avviser felles tankegods med Breivik" (Jensen rejects Breivik's ideas as common), Aftenposten, 2011 17:14 http://www.aftenposten.no/nyheter/iriks/Jensenavviser-felles-tankegods-med-Breivik-5014942.html\#.UySTuZJP67o

*** "Jonas Gahr Støre går ut mot Frp-anklager" (Jonas Gahr Støre reacts against accusations on the Progress Party), VG, 28/07/2011, http://www.vg.no/nyheter/innenriks/terrorangrepet-22-juli-politikk-ogsamfunn/jonas-gahr-stoere-gaar-ut-mot-frp-anklager/a/10080937/

*** "Politikk fra A til $\AA$ " (Politics from A to Z), Venstre (The Liberal Party), http://www.venstre.no/ artikkel/45742

*** "Siv Jensen: - "Bhatti kan gjerne finne seg et annet land" (Bhatti may well find himself another country), VG, 21.01.2012, http://www.vg.no/nyheter/innenriks/norskpolitikk/siv-jensen-bhatti-kan-gjerne-finne-seg-et-annet-land/a/10076250/

*** "Det kan ikke aksepteres at grunnleggende vestlige verdier og menneskerettigheter blir satt til side av kulturer og holdninger som enkelte grupper av innvandrerne tar med seg til Norge", Fremskrittspartiet, (The Progress Party)http://www.frp.no/nor/ mener/En-enklere-hverdag/FrP-fra-A-til-AA\#id38159 
*** "Innvandring og integrering," (Immigration and Integration) Arbeidspartiet (The Labor Party), http:/ / arbeiderpartiet.no/Politikken-A-AA/Innvandring-og-integrering.

*** 2014 UNHCR regional operations profile - Northern, Western, Central and Southern Europe, UNHCR, http:/ / www.unhcr.org/ pages/49e48ed26.html

*** Immigrants and Norwegian-born to immigrant parents, by country background. 1 January, 2014; Statistisk Sentralbyrå, http://www.ssb.no/en/innvbef

*** Immigrants and Norwegian-born to immigrant parents, by country background. 1 January, 2014; Statistisk Sentralbyrå, http://www.ssb.no/en/innvbef
$* * *$
Senterpartiet
(The
Center
Party),

http:/ / www.senterpartiet.no/i/category12992.html\#_Toc247 513954

*** The European Election Database, Norway - Political parties, http://www.nsd.uib.no/ european_election_database/country/norway/parties.html

Anders Johansen, Per. "Så lett er det å få falsk identitet i Norge" (A false identity is easy to get in Norway), Aftenposten, 2013 09:25, http:/ / www.aftenposten.no/nyheter/iriks/Sa-lett-er-det-a-fa-falsk-identitet-i-Norge7118388.html\#.UyYO_JJP4j

Andersen, Mads A., "Stoltenberg: -'Ytringsansvar» er et upresist begrep'” (Freedom of Responsibility is an imprecise term), VB, 22/12/2011, http://www.vg.no/nyheter/innenriks/ stoltenberg-regjeringen/stoltenbergytringsansvar-er-et-upresist-begrep/a/10024756/

Barstad, Stine, "Stoltenberg advarer mot heksejakt på ytringer" (Stoltenberg warns against the witch-hunt on rhetoric), VG, 18.okt. 2011, http://www.aftenposten.no/nyheter/iriks /Stoltenberg-advarer-mot-heksejakt-paytringer-6282315.html\#.UyMhiZJP67o

Beckmann-Dierkes, Norbert, Johann C. Fuhrmann, “Immigration Country Norway Demographic Trends and Political Concepts"; KAS International Reports, 2 |2011, pp. 36-48.

Behring Breivik, Anders, (Andrew Berwick), 2083 - A European Declaration of Independence, p. 31. (pages may differ, since the .pdf file spread in different versions.)

Boe Hornburg, Thomas, "22. juli-rapporten kommer Frp til unnsetning" (22nd of July Report comes to Progress Party's help), Aftenposten, 14.aug. 2012 http://www.aftenposten.no/meninger/ kommentarer/22-juli-rapporten-kommer-Frptil-unnsetning-6965629.html\#.UyQsf5JP67o

Fairclough, Norman (1995) Critical Discourse Analysis. (London, Longman), p. 6.

Falkheimer, Jesper and Eva-Karin Olsson, "Depoliticizing terror: The news framing of the terrorist attacks in Norway, 22 July 2011", Media, War E Conflict, 1 May 2014, p. 12.

Fondenes, Eivind; Kathleen Buer (23 July 2011). "Terrorsiktede var tidligere medlem av Fremskrittspartiet", TV2, http://www.tv2.no/nyheter/innenriks/terrorsiktede-vartidligere-medlem-av-fremskrittspartiet-3544743.html

Færaas, Arild, "Lokal Frp-topp om massedrapene: - De første ofrene for norsk innvandringspolitikk " (Local Progress Party Leader on the Mass Killings - The first victims of Norwegian Immigration Policy), VG, 13/08/2011, http:/ / www.vg.no/nyheter/innenriks/frp/lokal-frp-topp-om-massedrapene-de-foersteofrene-for-norsk-innvandringspolitikk/a/10081215/ 
Hopperstad, Morten, "Partisekretær Raymond Johansen (Ap): Mistet våre fremste talenter(Party Secretary Raymond Johanson - We lost our greatest talents), Aftenposten, 06.06.2012, http://www.vg.no/nyheter/innenriks/terrorangrepet-22-julirettssaken/partisekretaer-raymon d-johansen-ap-mistet-vaare-fremstetalenter/a/10073600/

Nilssen, Dyveke, „Dette bringer alle i Norge sammen”, (This brings everyone in Norway Together), VG, 26/09/2011, http://www.vg.no/nyheter/innenriks/terrorangrepet-22-juli-politikk-ogsamfunn/dette-bringer-alle-i-norge-sammen/a/10080718/

Skjervold, Helle, "Beklaget Sandberg-utspill og angrep Eskil Pedersen" (Sandberg regrets having attacked Eskil Pedersen), Aftenposten, 24.nov. 2011. http://www.aftenposten.no/nyheter/iriks/ Beklaget-Sandberg-utspill-og-angrep-EskilPedersen-6705791.html\#.UyV_K5JP4j8

Sørlie, Eivind, "Sandberg: «Ap har spilt offer» etter 22. Juli" (Sandberg: "Labor has played victim" after 22 July), Aftenposten, Nov 23rd. 2011, http://www.aftenposten.no/nyheter/iriks/Sandberg -Ap-har-spilt-offer-eter-22-juli6704751.html\#.UyV_TZJP4j8

Torgersen, Hans Henrik, "Frp-velgerne støtter Hagen etter terror-utspill" (Progress Party Voters Support Hagen with terror-act related initiative), VG, 17.08.2011, http://www.vg.no/nyheter/innenriks/valget-2011/frp-velgerne-stoetter-hagen-etterterror-utspill/a/10081530/

Wiggen, Mette (2012) "Rethinking Anti-Immigration Rhetoric after the Oslo and Utøya Terror Attacks", New Political Science, 34:4, 585-604. 